IMAGES IN CLINICAL MEDICINE

\section{Type 3 Scleredema}

(Scr Med 2011;42:31)

\section{August A. Natalie}

Stroger Hospital of Cook County

Department of Internal Medicine

Division of Dermatology

Chicago, Illinois 60612

USA

\author{
Correspondence \\ August A. Natalie, MD \\ Stroger Hospital of Cook County \\ Division of Dermatology \\ Chicago, Illinois 60612 \\ USA \\ Email: anatalie@gmail.com
}

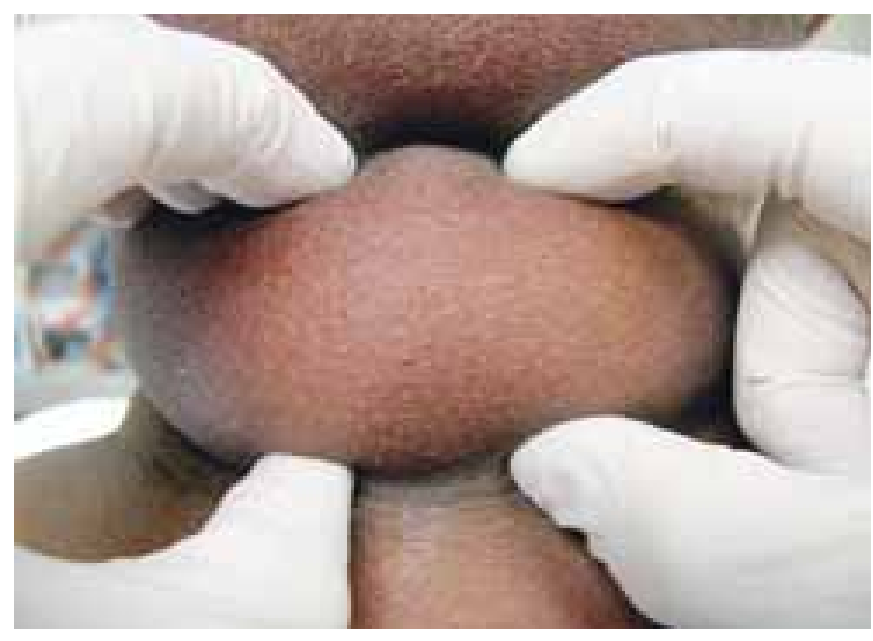

A 55-year-old male with type 2 diabetes mellitus, last glycated hemoglobin (A1c) 11.80, was referred to the dermatology clinic with a posterior neck mass. The primary care physician performed a CT scan of the neck, which revealed a prominence of subcutaneous fat, but no identifiable mass. Serum protein electrophoresis showed no obvious M-spike. Additionally, an incisional wedge biopsy of the posterior neck revealed no evidence of an underlying lipoma. Instead, the histopathology included a markedly thickened dermis extending past the sweat gland coils, and there were thick collagen bundles separated by clefts. Colloidal iron staining showed increased mucin deposition between the collagen bundles, supporting a diagnosis of type 3 scleredema.

Comment. Skin manifestations of diabetes mellitus occur in approximately 30\% of patients during the course of their illness. ${ }^{1}$ One such manifestation is scleredema, also known as scleredema adultorum and scleredema diabeticorum of Buschke. This condition is characterized by a diffuse, symmetric, non-pitting induration of the skin that usually involves the upper back, shoulders, and neck. The onset of scleredema is insidious, and it is usually found incidentally by the examining physician. ${ }^{2}$ Major consequences of this disease include decreased mobility of the shoulders, impairment of respiratory function, sleep apnea, and monoclonal gammapthy. ${ }^{3}$ It is believed the skin changes are caused by deposition of glycosaminoglycan within the dermal connective tissue. On histological examination, the reticular dermis is obviously thickened with mucin deposition between the thickened collagen bundles.

There are three types of scleredema adultorum. Type 1 is usually proceeded by a febrile episode (commonly caused by Streptococcal infections), type 2 involves developing paraproteinemias, including multiple myeloma, and type 3 is associated with diabetes mellitus.

The prevalence of scleredema in adult diabetic patients has been only minimally examined. The largest prospective study to date, consisting of 484 diabetic outpatients, reported a prevalence of $2.5 \% .^{4}$

Scleredema may be associated with both type 1 and type 2 diabetes mellitus. ${ }^{3}$ Risk factors for development of scleredema in conjunction with diabetes include: long duration of diabetes, the presence of microangiopathy, being overweight, the need for insulin, and presence of albuminuria. ${ }^{3}$ It is generally felt that glycemic control does not affect the condition.

\section{References}

1. Ahmed I, Goldstein B. Diabetes mellitus. Clin Dermatol 2006;24:237-46.

2. Venencie PY, Powell FC, Su WP, et al. Scleredema: a review of thirty-three cases. J Am Acad Dermatol 1984;11:128-34.

3. Meguerditchian C, Jacquet P, Beliard S, et al. Scleredema adultorum of Buschke: an under recognized skin complication of diabetes. Diabetes Metab 2006;32(5 Pt 1):481-4.

4. Cole GW, Headley J, Skowsky R. Scleredema diabeticorum: a common and distinct cutaneous manifestation of diabetes mellitus. Diabetes Care. 1983;6:189-92. 